\title{
Eski ve Yeni (!) Arasında Devlet, Eğitim ve Gençlik
}

\author{
Between Old and New (!): The State, Education and Youth
}

\section{Fatih Ertugay}

\section{Öz}

Yeni kuşakların (çocuklar ve gençler) ortak bir aidiyet hissi sağlamaları ve içine doğdukları toplumla bütünleşebilmelerinde eğitim, bir yöntem ve vas1ta olarak görülmüsşür. Bir hayli uzun bir tarihi olan eğitim, modernleşmeyle birlikte biçim, içerik ve işlev farklılaşmasına uğramış; modern devletler elinde farklı anlamlar yüklenip, devleti önceleyen hedefler tahsis edilerek seferber edilmiştir. Modern ulus devlet biçiminde inşa edilmeye çalışılan Cumhuriyet Türkiyesi'nde de, eğitim böylesi bir tahsis ve seferber edilmeden azade kalamamıştır. Eğitim, yeni rejimin yeni yurttaşını yetiştirmek hedefiyle, bir hayli yüklü bir muhtevayla başat bir etkinlik alanı olarak görülmüştür.

Eğitimin başat bir faaliyet alanı olarak görülmesiyle onun etkinliği ve başarısı arasındaki ilişki ise oldukça tartışmalı bir konudur. Tüm cumhuriyet dönemi boyunca da tartışmalı olan bu konu ve durumun, belirli bir paradigma ve anlayış değişiminin yaşandığ yeni dönemde aldığı ve alacağ biçim ise, en az bir önceki tartışma kadar önemlidir. Çalışma eski-yeni dikatomisi bağlamında, söz konusu eğitim sürecinin çıktıları olarak Türkiye'deki gençlerin durumlarındaki değişimi incelemeyi amaçlamaktadır. Bu incelemede merkezi kavramlardan biri de iyi yurttaş-iyi insan eşitlemesi olacaktır.

Anahtar Kavramlar: Eğitim, Devlet, İdeoloji, Yurttaş, Eski, Yeni

Yrd. Doç. Dr., Nuh Naci Yazgan Üniversitesi, İktisadi ve İdari Bilimler Fakültesi, Siyaset Bilimi ve Kamu Yönetimi Bölümü, fertugay@hotmail.com

Bu makale iThenticate sistemi tarafından taranmıştır.

DOİ: 10.17550/aid.08714 


\begin{abstract}
Education is seen as a means and method of common sense of belonging and integrating with were born into society by new generations (children and young people). Quite long history of education undergoes a change of manner, content and function with modernization; it is attributed a different meaning by modern states and it is mobilized by setting targets that prioritizing the states. The Republican Turkey is tried to be built in a shape of modern nation state as well, education cannot be safe from such a setting and mobilizing. Education is seen with quite well content as a leading domain via target of new regime and its new citizens. Together with this, the relationship between effectiveness and achievement of education is a quite debated subject. This subject and situation are debated during all republic period which took and have been taking form in new paradigm and understanding changes, is just as important as the previous debate. This study aims to research changes in situations of young people in Turkey as outputs of education in the context of old-new dichotomy. In this research on of the center concepts is equalization of good citizen-good person.
\end{abstract}

Keywords: Education, State, Ideology, Citizen, Old, New. 


\section{Giriş}

Eğer siyasal elitlerin tasavvur ettikleri yeni yurttaşı yetiştirmek başarının ölçüsü olarak kabul edilecekse, bu anlamda Cumhuriyet tarihi bir başarı hikâyesi olarak kabul edilebilir. Yok, eğer kendi benliğinin farkında, özgün ve özerk, sosyal duyarlılığı gelişmiş, kendisini ifade edebilen, engelsiz olarak düşünebilen, sorgulayan, eleştiren, yeri geldiğinde itiraz eden bireyler yetiştirmek gibi bir beklenti söz konusu ise, bir başarıdan söz edebilmek tartışmalı hale gelir.

Başarı, bu anlamda yalnızca okullaşma, derslik ve eğitimci sayıs1 ile ölçülebilecek bir durum olmaktan çıkmaktadır. Eğitimde yeni paradigmaların, yeni anlayışların çoktandır gündemde olduğu, alternatif eğitim modellerinin tartışma zemininden çıkıp, uygulamaya dönüştüğü bir ortamda; hâlâ devletin, eğitimde ana aktör olduğu, eğitimi resmi ideoloji merkezli planladığı ve kurguladığ 1 bir vasatta, yaratıcı, yeniliğe açık, alternatif düşünce ve yaşam tarzlarına karşı hoşgörülü, adalet fikrini içselleştirmiş özgün ve özerk bireylerin ortaya çıkması bir hayli güçtür. Bu nedenle eğitimin, belirli bir yurttaş tipi yetiştirilmesine odaklanan bir etkinlik olmaktan çıkarılması gerekmektedir. Yoksa bu ideal yurttaş tipinin muhtevasının değiştirilmesi, başka bir anlatımla ideal bir yurttaş tipinden başka bir ideal yurttaş tipine geçiş, sistemin tüm temel sorunlarını bir anlamda 1skalamak anlamına gelecektir. Sosyal ve siyasal düzenin istikrarı bağlamında gençlerin, belirli bir ortak aidiyet $^{l}$ duygusuna sahip bireyler olarak yetişmelerinin gerekliliği bir

1 İnsan, var oluşsal açıdan bir grup-varlıktır. Dolayısıyla 'ben kimim?' sorusuna verilen cevabın oluşturduğu 'bireysel kimlik' ile her zaman belirli ölçülerde 'biz kimiz?' sorusuna verilen cevap yan yanadır; yani mensubiyet ve aidiyet unsurlarını da içermek zorundadır (Göka, 2006: 297). Dolayısıyla kolektif bir yapı içerisinde birey, bireysel özelliklerinden arınarak toplumsal yapının kendi muhtevasında bir yer edinmeye çal1şır. Bu nedenle sosyal kimlikteki asıl vurgu ya da etmen kolektifliğe yöneliktir (Yanık, 2013: 226). Bu kolektiflik bireyin, bireysel kimliği/kimlikleri ile kolektif siyasal ve toplumsal yapı arasındaki asgari uyumu ve örtüşmeyi ifade eder. Netice itibari ile belirli bir siyasal ve toplumsal hinterland içerisinde bireylerin, o sınırlar içerisinde kalmayı anlamlı bulma derecesi ortak aidiyet kavramını var eder. Bu ortak aidiyet, benzer ve aynı olmaya gönderme yapmamakta; fakat pek çok farklı kimliklere sahip olan bireylerin, bu farklılıklarıyla birlikte siyasal ve toplumsal sisteme dâhil olma isteğini, sistemin bir parçası olma inancını ve sistemin eksiklikleriyle beraber gerçekleşebilir alternatiflerine tercih edilebilir olduğuna dair kanaatlerini ifade eder. Buna göre ortak aidiyet, bir kimsenin içinde bulunduğu yapıların karakteristiğini tanımlaması ile ilgilidir. $\mathrm{Bu}$, bir ya da daha fazla bireyin ortak bir toplumsal kimlik tanımlamasını paylaştığı ya 
gerçeklik olmakla beraber, bunun bir bağımlılık ve sadakat ilişkisi şeklinde anlaşılması ve uygulanması bir zorunluluk değil; aksine iktidar ilişkileri çerçevesinde düşünülecek olan bir pratik ve tercih olacaktır. Bu nedenle yeni'nin eski' den ${ }^{2}$ farklılaştığ 1 oranda, kendi iç dinamikleri ve ruhuyla uyumlu bir şekilde, eski'nin bütün anlayış ve uygulamalarından tümüyle kopması, ondan ayrışması, gençlerin birer birey olarak yetişebilmelerini mümkün kılacak bir çaba olarak atılması gereken önemli adımlar olacaktır. Bunun nasıl gerçekleşebileceği, farklılaşmanın hangi noktalarda gerekli olduğu, eski ile yeni'yi ayıranın ne olduğu soruları; temel sorunlar, geçişkenlikler ve öneriler bağlamında çalışmanın ana eksenini oluşturacaktır.

\section{İktidar-İtaat Ve Ortak Aidiyet Geriliminde Eğitim}

Modernleşmenin siyasal boyutunu oluşturan modern ulus devletin önce kavramsal olarak düşünülmesi, sonrasında da hukuki ve pratik olarak ortaya çıkması, eğitim düşüncesi ve uygulamalarına da doğrudan etki etmiştir ${ }^{3}$. Bu süreçte eğitim, Üstel'in belirttiği gibi modern merkezi devletin gelişimi ve konsolidasyonunda dönüştürücü rolünün siyasal seçkinlerce teşhisiyle (2009: 11) önemli bir nitelik kaymasına uğramıştır ${ }^{4}$. Devlet eğitime el atarak, eğitim sürecindeki çeşitli unsurları

da kendilerini aynı toplumsal kategorilerin üyeleri olarak algıladıkları yeri ifade eder (Hogg ve Abrams, 1998: 7).

2 Aşağı yukarı son on yıldır Türkiye'deki cari iktidar formüllerini ve pratiklerini değiştirdiğini varsayan bir siyasal hareketin, kendisi ile birlikte ortaya çıkan durumu "yeni" ve önceki dönemi ve durumu "eski" olarak adlanlandırması/iması ile karşı karşıya bulunulmaktadır. Belirli ölçülerde kabul edilebilir bir gerçekliğe tekabül ettiği de doğru olan bu imanın, önemli önemli içeriksel noktalarında eski ve yeni arasındaki ayrımın yalnızca bir dönemlendirmeden ibaret olduğunu söylemek yanlış olmasa gerektir. Çalışmadaki eski ve yeni karşılaştırması böylesi bir muhtevaya ve devlete bakışta temeldeki bir sürekliliğe işaret etme amacı taşımaktadır. Bu noktada çalışmanın pür bir eğitim felsefesi tartışması ve eleştirisi olmadığını; daha ziyade siyasal bir öze ve önceliğe sahip olduğunu belirtmek yerinde olacaktır.

3 Modern devletin ortaya çıkışı, pratikleri, kurumları ve modern devletle ilgili bir dizi tartışma için şu kaynaklara bakılabilir. (Creveld, 2004; Anderson, 1996; Wight, 1977; Poggi, 2005; Cassirer, 1983; Schulze, 2005).

4 Eğitimin devlet iktidarının tesisi için taşıdığı önem ilk defa modern devletle anlaşılmış olmamakla birlikte, eğitimin yaygın, sürekli ve belirli bir müfredata tabi, kontrol edilebilir ve endoktrine edilebilir niteliklerinin hepsinin bir arada bulunduğu bir şekilde tebarüz etmesi yenidir. Bununla birlikte eğitimin iktidar için taşıdığı önem, antik çağdan beri üzerinde durulan konulardan biridir. Örneğin Platon, bu konuyu incelikli 
kullanmak suretiyle toplumsal bir birliktelik ve bütünlük sağlamaya çalışmıştır. Eğitim, ortak değerler etrafında kaynaşan bir yurttaşlar topluluğunun yaratılmasının en önemli aracı olarak görülmüştür. İnal'ın belirttiği gibi milli marş, bayrak, milli bayram, törenler, ulusal önderler ve kahramanlarla, başka bir ifadeyle milli simgelerle amaçlanan dayanışma, sadakat ve aidiyet, milli bilinç ve kimliği kolektifleştirme; toplumsal düzen, yasalar, kutsal nesne ve simgelere ve geçmişe sayg1 göstermek, milli ideolojinin meşruiyetini güçlendirip (1999: 198) yeni modern devletin gelişiminin sürekliliğini sağlanmayı amaçlamıştır.

Devletle eğitim arasındaki bu ilişkinin en ayırt edici örneğini Fransa oluşturmuştur. Fransa'da 1882 tarihli eğitim yasalarıyla ilkokul öğretmenleri öğrencilerinde öncelikle "Cumhuriyet, Fransa, Vatan ve Devlet Aşkı”nı geliştirmekle sorumlu kılınmışlardır. Bu bağlamda söz konusu eğitim, çocukları bir yandan Kilise'nin değerler sisteminden özgürleştirmeyi amaçlarken, diğer yandan da Tanrı'ya, ebeveynlere ve otorite(lere)ye saygıya dayalı yeni bir ahlak anlayışı geliştirmeye yönelmiştir. Bunun sonucunda eğitim, ahlak ve yurttaşlık dersleri ile tarih ve coğrafya derslerinin de yardımıyla geleceğin yurttaşlar topluluğunun inşası yolunda önemli bir işlev kazanır (Üstel, 2009: 21). Böylece devlet, elinde bulundurduğu tüm imkânlarla topluma, kendi ideolojik ilkelerini öğreten, toplumu bu ilkelere göre terbiye eden bir kurum halini alır. Eğitim aracılığıyla devlet, tüm halkın düşünce ve değer yargılarının bir 'eritme potası' içinde kaynaştırılıp bütünleştirilmesini gerçekleştirme amacına yönelmiştir (Black, 1989: 114).

Eğitim bir yandan yurttaşlık inşasında, yurttaşları ahlaki yönden yükseltmek, yasalara saygı duymalarını ve itaat etmelerini sağlamak, bireysel ve toplumsal görev bilincinin biçimlenmesine katkıda bulunmak anlamlarına gelirken, aynı zamanda belirli toplumsallık biçimlerini teşvik etmek, siyasal amaçlar doğrultusunda yurttaşlık bilinci ve duyarlılığı oluşturmak anlamlarını taşır hale gelmiştir. Burada temel amaç, ulusun ahengini ve birliğini güçlendirecek yurttaşlık tutum ve davranışlarını oluşturmak ve bunlara süreklilik kazandırmak olmuştur. Bu sayede bireylerin davranışlarını kontrol altına almaları, kendilerini diğer yurttaşlarla bağlayan bağlara özen gösteren kişiler haline gelme-

bir şekilde eserlerinde işlemiştir. Bu konudaki bir çalışma için bkz. (Rusk, 1965). 
leri, başka bir anlatımla ortak aidiyet duygusuna sahip kişiler olmaları sağlanmış olacaktır (Üstel, 2009: 22, 23). Bu yönüyle eğitim, anlam arayışındaki bireye ortak aidiyet duygusu vermesi bakımından rehberlik eden yardımcı bir unsur, diğer yandan da onun özgürlüğüne göz diken güçlerin bir ajanı olmakta ve bu yönüyle ciddi riskleri de içerisinde barındırmaktadır (Evkuran, 2009: 482). Zira eğitim, devletin varlığını, gücünü ve temel ilkelerini topluma kabul ettirebilmek için kullandığı en önemli ideolojik araçlardan birisidir. Devlet, toplumsal düzenlemeyi belirlediği ideolojik amaçlar ve ilkeler çerçevesinde yeniden kurmak için eğitimi kullanmaktadır (Çetin, 2001: 206).

Devletin belirlediği ideolojik amaçlar çerçevesinde eğitimi ve okulu kullanması ve okul eğitimini kutsallaştırması süreç içerisinde değerler krizine yol açmıştır. Okul mitleşirken toplumun geleneksel bilgi üretme ve aktarma mekanizmaları çökertilmiş; eğitim, en temel işlevi olan bireylerin zihnini insanî mirasa açmak ve onunla sağlıklı ve üretken bir iletişim kurmalarını sağlama görevinden uzaklaşmıştır (Evkuran, 2009: 482). Her ne kadar eğitimin, her türlü bilgi aktarımı$\mathrm{n} 1$ ve değerler oluşturmayı kapsaması anlamında toplumsallaştırma ile eş anlamlı olduğu ifade edilse de (Anderson, 1968: 517); esas olarak eğitimin bir de siyasal yani ideolojik boyutu vardır ki, bu da siyasal mesajların/ideolojinin iletilmesiyle siyasal bilginin her türlü iletişimini ve siyasal değerlerin oluşturulmasını içerir (Greenstein, 1968: 554). Dolayısıyla burada modern devletin çatısı altında belirli bir ideolojinin topluma yukarıdan aşağıya benimsetilmesi birincil öncelik olmuştur. Bu çerçevede eğitim kurumlarının üstlendiği görev de çok net olarak tanımlanmıştır. Resmî ideolojinin bireylere benimsetilmesi, istenen nitelikte bireylerin yetiştirilerek sisteme kazandırılması ve bunlar üzerinden yeniden tüm bir toplumun düzgünleştirilmesi, uygulanan eğitim programlarının temelindeki felsefî (ideolojik) ilkeyi oluşturmuştur (Evkuran, 2009: 486). Bu anlamda eğitim, toplumsal bir amaca ulaşmak için bir araç olarak kullanılmıştır. Eğitim süreci, insanın imal edilme sürecini ve fabrikasyonunu ifade eder hale gelmiştir. Bu yönüyle eğitim kurumlarını, insanları programlama merkezleri olarak değerlendirmek yanlış olmayacaktır (Illich, 1988: 65-67).

Modern devletin, gençleri kalabalıklar halinde okullara koymasının ve öğrenimlerini dikkatli bir şekilde yönetmelerinin sebebini burada aramak gerekir. Buradaki temel amaç, "insan doğasının kendini 
bilme, merhamet, barışseverlik, adalet duygusu, yaşama saygı, derin kökleri olan bilgelik gibi insanın kibar ve daha asil niteliklerini ilerletmek" değildir; tam tersine, insanları sosyal, ekonomik ve politik sistemlerin kişilikdışı rutinlerini kabul eden itaatkâr isçiler, tüketiciler ve seçmenler haline sokmaktır (Miller, 2010: 25). Başka bir anlatımla toplumsal süreklilik için gerekli olan ortak aidiyet bilinci oluşturmanın ötesinde, itaate koşullandırılmış iyi insanlar/iyi yurttaşlar yetiştirmektir. Böylece artık, birey adına düşünen ve karar veren üst bir otoritenin varlığı meşru ve gerekli görülecek; ve o, her şeyi olduğu gibi eğitimi de standartlaştıracak, kategorize edecek, sınıflayacak ve onunla ilgili her türlü tasarrufu yapacaktır.

\section{Ortak Aidiyet Bilinci Ve Ortak İtaat Bilinci Arasında Türkiye'de Gençler}

Modern bir devletin inşa edilme ve konsolidasyon süreci ve çabalarının nesnesi olan gençler, bu çaba ve sürecin tüm olumsuzluklarıyla birincil muhatap/hedef olarak yüzleşmek zorunda kalmışlardır. Siyasal elitler, bir yandan tüm kurum ve pratikleriyle modern bir devlet kurmaya çalışırlarken, bir yandan da yalnızca kamusal hayata değil, aynı zamanda özel alana da sirayet etmesini öngördükleri ilke ve kabulleri yerleştirmeyi amaçlamışlardır. Bu doğrultuda da başta okul ve eğitim olmak üzere, tiyatro, mimari, müzik, resim, edebiyat ve benzeri birçok alanda planlamaya gitmişler, düzenlemeler gerçekleştirmişlerdir. Aydınlanmacı ve pozitivist bir formülasyonla meşrulaştırılan tüm bu çabaların özünde, devletin kişisini, onun iyi yurttaşını yetiştirmek kaygısı yatmaktadır. Bu algı ve pratikleri daha iyi anlamak için ilk önce Türk modernleşmesinin temel dinamiklerini ve saiklerini incelemek gerekir.

\section{Türk Modernleșmesi Ve Yansımaları}

Türk modernleşmesi, elit merkezli, yukarıdan aşağıya inen hiyerarşik bir yapıya sahip, devlet odaklı, kurtarıcılık misyonu içeren, toplumsal refahın sağlanması ve toplumsal iyinin amaçlanmasından çok, ülkenin dış ilişkilerdeki konumunu güçlendirmeyi öngören, ivmesinin toplumda değil siyasal alanda ortaya çıktığı, ağırlıklı olarak bürokratik bir anlayışa dayalıdır. Ayrıca bu modernleşme, belli bir grup tarafindan biçimlendirilmesi nedeniyle kontrollü bir modernleşmedir (Kahraman, 2008: 5; Bilgin, 2002: 72). Bu yüzden de devletin modernleşmeye ba- 
k1ş açısı, daima modernleşmenin kendisine sunduğu, toplumu düzenleme ve kontrol etme imkânı nispetinde olmuştur (Çetin, 2007: 172). Bu nedenle Türk modernleşmesi, halk yığınları için hiçbir zaman aktif bir katılım sürecini doğurmamış, alt ve üst sınıfların veya kültürlerin yeni bir iktisadi, siyasal ve sosyal düzen içinde bütünleşmelerini sağlayamamıştır (Mardin, 2006: 33). Bu bakış açısıyla Türk siyasal modernleşmesi elit bir grubun yönlendirmesine bağlanmıştır. Toplumun geniş kesimleri, elitleri bu süreçte izlemelidir (Kahraman, 2008: 11; Bilgin, 2002: 78). Bu anlayış modernleştirici devlet ve modernleştirici aydınlar kavramlarının çakışmasına ve aydınların yeni bir kategori olarak devletle bütünleşmesine yol açmıştır.

Devletle bütünleşen modernleştirici aydınların ve çağdaşlaştırma misyonu doğrultusunda hareket eden siyasal elitlerin kuramsal olarak hareket ettikleri ya da kendilerine referans aldıkları değerler ise, tıpkı içinden çıktıkları ve kendilerinin öncülleri olan Jön Türklerde olduğu gibi, pozitivist bir akılcılık ve siyasal anlamdaki halkçılık olarak görünmektedir (Hanioğlu, 2001: 55). Her iki ilke de devletin, toplumu kurması ve düzenlemesini sağlama yönünde işlev görmüşlerdir. Ayrıca toplum ileriye dönük bir değişim projesinin aracı haline getirilmiştir. Dolayısı ile devlet, kamusal alanda denetim, üretim ve yeniden dağıtımı düzenlemek amacıyla toplumun tüm kaynaklarını seferber edip rasyonel biçimde kullanma istekliliği içerisine girer (Çetin, 2007: 181). Buna bağlı olarak da Cumhuriyet'in kurucu elitleri, devlet kurtarıldıktan sonra, devletin bekası doğrultusunda toplumu ilerletmek ve bunun için de yeni bir toplumsal siyasal örgütlenmenin gerekleri doğrultusunda hareket etmişlerdir. Son kertede bu kurucu elitler, hem devlete araçsal açıdan önemli işlevler yüklemiş ve hem de devlet-toplum bütünlügünün ideolojik ve kurumsal zeminini etmişlerdir. Sonrasında ise, bürokratik bir nitelik alan bu elit grup ${ }^{5}$ tarafından şekillenen idari olarak merkezi, farklılık ve otonomiye anlayış göstermeyen, vatandaşın kendisine mutlak itaatini bekleyen kıskanç bir Tanrı niteliğinde olan ve egemen bir devleti öngören bir siyasal düşünce toplum üzerinde hâkimiyet kurmuştur (Toynbee ve Kirkwood, 1927: 4).

5 Siyasal felsefesi milliyetçilik, halkçılık ve halk egemenliği ilkesine dayalı bu yeni elit, 1920'lerin başında Türk siyasal hayatında çok küçük bir gurubu oluşturuyordu (Heper, 1974: 96). 
Türk kimliğinin devlet eliyle biçimlendirilmesi, devletin bekas1 doğrultusunda toplumun ilerletilmesi (!) ve bu doğrultuda siyasal bir bilinç oluşturulması, yeni yurttaşın var edilmesi işinde, diğer modernleştirme örneklerinde görüldüğü gibi, seferber edilen en önemli enstrüman eğitim olmuştur. Türk siyasal elitleri, bu bağlamda, eğitime özel önem vermişler; toplum mühendisliğinin eğitime yansıması olan pedagojik mühendislik alanında özel uygulamalar geliştirmişlerdir.

\section{Eski: İyi İnsan Eşittir İyi Yurttaş}

Siyasal modernitenin bir gereği olarak görülen modern bir kamusal alanın kurgulanması, yurttaşlığın bir davranış mühendisliği çerçevesinde ele alınması gibi bir sonucu doğurmuştur. Siyasal sistemin arzu ettiği iyi yurttaş ${ }^{6}$, aynı zamanda iyi insan da demektir. Erdemli yurttaşlar - iyi insanlar, sistemin yalnızca hukuki değil, ahlaki bir rejim olmasının güvencesidir. Bu anlamda Cumhuriyetçi paradigma içerisinde okuldaki yurttaş eğitiminin iki öncelikli hedefe yönelik olduğu görülür: Medeni ve yurtsever yurttaşın yaratılması. Siyasal elitlerin yurttaş tasavvurunun medenilik boyutu, geçerli olarak kabul edilen davranış kodlarının telkinini içerir. "Çağdaşlık-yurttaşlık" temelinde biçimlenen bu anlayış, Cumhuriyet batıcılığının bir yansıması olarak kişi ile devlet arasında hukuksal ve siyasal bir aidiyet olmanın ötesinde belirli bir yaşam biçimi ve toplum projesini de varsaymaktadır (Üstel, 2009: 323).

Siyasal elitler tarafından inşa edilmek istenen medeni yurttaş profilinin temel özelliği, onun sivil değil militan olmasıdır. Bu militan yurttaş profili, üç temel eksene oturtulur: Yurtseverlik, hak ve vazife, tehdit/tehlike alg1s1. "Cumhuriyet'e yurttaş yetiştirmek" mottosu ile hareket eden siyasal elitlerin (Katoğlu, 1989: 473) yurttaş profilinin olmazsa olmaz koşulu yurtseverliktir. İkinci nokta, yurttaşlığı tanımlayan hak ve vazifeler sistematiğiyle ilgilidir. Kendine, ailesine, milletine ve devletine görevlerinden hareketle tanımlanan yurttaş, kuşatıcı ama böyle olduğu kadar da bir apolitiklik ve kamusallık üzerinden tanım-

6 Yurttaş, oldukça geniş bir tanımlama olmakla beraber (nüfusun neredeyse tamamı), çalışma açısından bu tanımlamada önemli olan dönemlendirmenin, yurttaşın bilinç düzeyinde var edildiği/inşa edildiği, başka bir anlatımla yurttaşlık bilincinin verildiği yıllara denk gelmesi bakımından geç çocukluk ve gençlik yılları olduğu akılda tutulmalıdır. 
lanmıştır. Militan yurttaş profilinin dayandığı son noktayı oluşturan tehdit/tehlike algısının temel işlevi ise, "öteki”nin işaret edilmesinden oluşan bir zihinsel seferberlik durumunu toplum üzerinde egemen k1lmaktır. Sivil olmayan bu yurttaşlık tasavvuru aynı zamanda, toplumu oluşturan yurttaşların tümünün, tanımlanmış ve değişmez bir iyi yaşam ve ortak yarar fikrini de (Üstel, 2009: 323, 324) paylaştıkları ya da paylaşmaları gerektiği zorunluluğunu içermektedir. Bu ortak yarar ve iyi yaşam tasavvurunun kurgulanması ise, geniş bir biçimde tanımlanmış ve yurttaşın özel yaşamının da önemli bir kısmını kapsayan, düzenleyen, denetleyen, dolayısıyla da kamusallığı şüpheli bir bakışla yapılır. Bu kamusal alanın temel aktörü, özgür ve özerk yurttaş değil, bunun yerine sosyal yönünü genel yarara uygun olarak düzenleyen yurttaştır (Üstel, 2009: 326). Öyle ki, bu yurttaş (genç), devletine karş1 görevlerinin ve sorumluluklarının bilincinde olan ve bunları davranış kuralı haline getirmiş olan bir kişi olacaktır. Yurttaştan beklenenler bunlarla sinırlı değildir. Öncelenen beklentilerden biri de sadakat ve buna ilaveten fedakârlıktır. Devlete sadakat ve devlet için fedakârlık, övülür, teşvik edilir ve istenir bir erek olarak resmedilir. Bu anlamda gençlik, daha doğrusu ideal gençlik, her türlü aşırı ve ayrımcı düşüncenin, farklı siyasal-sosyal tercihlerin, eleştirel hareketlerin ortaya çıktığ 1 bir sosyal küme değil; bunun aksine düzen, kontrol ve disiplinin esas olduğu, devlete bağlılık ve sadakatin içselleştirildiği, aynı şekilde devlet büyüklerine ve devlete saygının bir davranış kodu haline geldiği, varlığını devleti için armağan edebilen kişilerden müteşekkil homojen bir bütünü ifade etmektedir.

Sivil ve katılımcı niteliklerin önemsenmediği, hatta iradi olarak dışarıda bırakıldığı böylesi bir yaklaşım içerisinde, bir pro-yurttaş olarak çocuklar ve gençler için neyin, kim tarafından ve hangi yöntemlerle öğretileceğinin belirlendiği (Kaplan, 2005: 386), pasif bir itaat davranışının alışkanlık haline getirileceği, öğrenme özgürlüğü ile bireyin özgünlüğüne değer verilmeyen bir eğitim felsefesi ve sistemi inşa edilmiş ve sürdürülmüştür. Buna eşlik eden korumacılık, kollayıcılık ve bunun temelinde yatan güvensizlik de, dolayısıyla bu algiya muhatap olanlarda da kendilerine ve çevrelerine dönük bir korkunun ve özgüven eksikliğinin derinleşmesine yol açmıştır. Güvensizlik aynı zamanda katışıksız/saf bir düşünce ve davranış normunun da vaz edilmesi ve bunun gençler tarafindan benimsenmesi beklentisini doğurur. Bunun 
içerisinde neyin, ne kadar sevileceğinin ve neyden ne kadar korkulacağının belirlenmesi de vardır. Zira itaatin sağlanması, çocukların ve gençlerin itaate alıştırılması sevgi ve eş anlı korkunun birlikte telkini ile mümkün olacak bir öğrenme davranışıdır. Bu anlamda Türk milli eğitim ideolojisi, 'beşikten mezara kadar' devam eden bir süreci kapsar ve bu sürecin her aşamasında toplum bilinçlendirilir, kendi bilincine vardırılır ki bu bilinç siyasal iktidara mutlak itaat etme görevidir. Yani bu sürecin özü, tüm gerçeği tanımlama, belirleme ve düzenleme yetkisinin ögreticiye ait olduğu düşüncesidir. Böylece, siyasal iktidar ideolojisinin ruhu beşikten mezara kadar toplumun düşün ve eylem dünyasının üstünde, siyasal iktidarın disiplinli, hiyerarşik, buyurgan öğretisinin emrinde olmaktadır.

Cumhuriyetin itaate bu kadar önem vermesinin başka bir nedeni daha vardır. O da, Türkiye Cumhuriyeti yurttaşlığının ${ }^{7}$ bir toyluk varsayımı üzerine inşa edilmiş olmasıdır. Buna göre, özgürleşmemiş, olgunlaşmamış toy zihinlere, onların talepleri öncesinde yurttaşlık kostümü giydirilmiş ve insanların yaşamları vazifelerle anlamlandırılmaya çalışılmıştır. Türkiye Cumhuriyeti yurttaşlarının muhakemeli değil iradeli olmaları beklenmiştir (Kadığlu, 2005: 288). Dolayısıyla henüz olgunlaşmamış, ki bu olgunlaşamama hali süreklilik arz eder, yurttaş olma durumu nedeniyle, başka bir anlatımla devletine ve kamuya karş1 vazife ve sorumluluklarının bilincine varamamış kişilerden oluşan bir topluluğun varlığı karşısında, eğitim vasıtasıyla bu kişilerin ve topluluğun, yurttaş haline getirilmesi ve itaatlerinin sürekliliğinin sağlanması yerinde ve gereklidir.

Evkuran'ın modern devletlerin iktidarlarını pekiştirmek ve meşruiyetlerini temellendirmek için eğitimi bir araç olarak kullanmalarının sonuçlarından bahsederken söylediği ifadeler, Cumhuriyet'in itaati sağlamayı temel alan ve toyluk varsayımı üzerinden yükselen eğitim politikalarının sonuçları üzerine konuşurken de son derece açıklayıcı olmaktadır (2009: 484): Çoğulculuk ve farklılık tehdit olarak algılanmaya başlamıştır. Bunun bir sonucu olarak tek tipleştirme ve bunun

7 Türkiye Cumhuriyeti'nde yurttaşlık olgusu, haklar ya da statü temelli AngloAmerikan geleneğinden farklı olarak, daha ziyade Cumhuriyetçi Fransız geleneğini, yani vazifeler temelli, vatandaşlığın belli pratikleri içerdiği bir anlayışı andırmaktadır (Kadığlu, 2005: 287). 
için otoritenin/baskının kullanılması uygun ve normal görülmüştür. Dolayısıyla böylesi bir otoriterlik ve sınırlandırma içerisinde entelektüel hayat da fakirleşmiştir. Bu fakirleşme, zihnin aşırı politikleşmesine paralel olarak diğer alanların özerkleşmesini de geciktirmiştir. Diğer toplumsal alanlar ve kurumlar reel siyasetin baskısı altına girmiştir. Bunların sonucu olarak da İnal'ın ifadesiyle çocuklar ve gençler, hem günlük hayat pratiği hem de kurumlar içinde tanımlanmış, büyük idealler adına yükümlü kılınmış; onlara büyük görev ve sorumluluklar yüklenmiş, terbiye edici pratiklerle tek biçimci bir dünya görüşüne itilmişlerdir. Bu bakış açısıyla çocuklar, biçimlendirilmesi, doldurulması ve yönlendirilmesi gereken toplumsal nesneler olarak görülmüşlerdir (1999: 210). Nesne olanın ise, doğal olarak bir özne olarak hareket etmesi mümkün değildir. Kaldı ki, böyle bir beklenti de söz konusu değildir. Zira beklenti kendi varlığının ve özgünlüğünün bilincinde olan, seçim yapabilen, eleştirel düşünebilen, kısacası birey olabilen gençler yerine, bunların hiçbiri olmayan iyi yurttaşlar olunca, özne olabilmek iddiası bir hayli uzaklarda kalmaktadır.

\section{Yeni (!): Özgün Ve Özerk Birey}

Yeni'nin en ayırt edici vasfinın pedagojik mühendislik yapmamak olması beklenir ${ }^{8}$. Zira eğitimi belirli ve onaylanmış bir yurttaş tipini yetiştirmenin öncelikli aracı olarak görmek, -kısa, orta ya da uzun vadede fark etmez- zihinsel açıdan ve yetenek bakımından kötürümleşmiş nesillerin yetişmesine neden olmaktadır. Zira devlet, pedagojik mühendisliği kendi amaçlılığ doğrultusunda kurguladığından sonuçta da devletçi mantıkla düşünen, bireyselliğinin ve özgünlügünün farkına varamamış kişilerin (varlığını devlete adayan kişi) ortaya çıkmasına neden olmaktadır 9 . Bunun yanı sıra bağlllık yaratmakla, ortak aidiyet bilinci oluşturmak arasında önemli farklar bulunduğunu belirtmek ge-

8 Yeni kavramı çerçevesinde eğitim konusunda postmodern dönem tartışmaları hakkında bir çalışma için bkz. (Aronowitz ve Giroux, 1997): Ayrıca postmodern dönemde küreselleşme ve neo-liberal politikaların eğitim üzerindeki etkileri ve eğitim ile olan ilişkileri hakkında şu kaynaklara bakılabilir (Dikkaya ve Özyakışır, 2006; Aydın, 2006; Smith ve Wexler, 2005; Hill, 2003; Hill, 2005).

9 George Orwell'ın 1984 adlı romanı bu konuda son derece çarpıcı bir örnek sunmaktadır. Korku, sevgi, endişe, öteki, düzen ve benzeri temalar etrafından yurttaşların sisteme bağlılıklarının nasıl yaratıldığı, pekiştirildiği ve sürdürüldüğü oldukça dikkat çekicidir. 
rekir. Toplumsal bir düzen için belirli oranda ortak aidiyet bilincinin varlığg şarttır, ancak bu, devlet kavramı etrafında oluşturulan bir bağlılıktan farklıdır. Dolayısıyla devlete koşulsuz itaati amaçlayan siyasal endoktrinasyon ile insanın/yurttaşın eğitiminin birbirinden ayrı şeyler olduğunun da altını çizmek gerekir. Buna göre, yurttaşlık eğitimi, iyi bir yurttaşın üyesi bulunduğu ulusun siyasal yaşamına nasıl katılacağına ağırlık verir ve kişiyi, bağlılığın varsayıldığı ulusla tanıştırır. Buna karş1lık, siyasal endoktrinasyon, belirli bir rejimi kabul ettirme ve haklı gösterme amacını güden belli bir siyasal ideolojinin öğrenilmesine ilişkindir ve ulusa bağlılık ve hatta bağımlılık aşılar (Dawson, Prewitt ve Dawson, 1977: 141). Dolayısıyla böylesi bir algı içerisinde Kadıoğlu'nun ifadesiyle Türkiye'de vatandaşlık vurgusu her zaman bireyselliği gölgede bırakmıştır (2008: 284). Zira tanışma ile bağlılık yaratma arasındaki mesafenin büyüklüğü oranında, itaat ve özerklik arasında bir mesafe oluşmaktadır. Tanıştırma, kişiye birey olma, yani seçim yapabilme imkânı tanırken; bağımlılık, sorgulamaksızın kabul davranışını pekiştirdiği için bireyselliği, tercih yapabilmeyi, eleştirel düşünebilmeyi engellemektedir. Bu nedenle yeninin en belirgin özelliğinin, ideolojiden arındırılmış bir eğitim anlayışını benimsemiş olmakta yattığını söylemek yanlış olmayacaktır. Bu da, en başta zihinlerin siyasal sisteme ait kutsallıklardan, korkulardan, abartılmış sevgilerden, hiyerarşik ilişkilerden, kesin inançlardan, mutlak ve tek taraflı doğrulardan arındırılmasından geçmektedir.

Tersinden bakıldığında hâlâ devletin, her şeye yeten/yetişen, her müşkülü halleden bir baba edası/sembolizmi üzerinden tasvir edildiği bir vasatta, bu tasavvuru içselleştiren zihinlerde bireysel hareket etme kapasitesinin, bir işi başarma istekliliği ve özgüveninin ve kamusal sorumluluk bilincinin sakatlanmayacağını düşünmek olası değildir. "Bir sorun varsa, bu sorunu çözecek devlet de vardır" varsayımı/beklentisi; hatta çözemezse bile, bir zaman çözecektir, çözmesi gereken adres orasıdır algısı, yeni yetişen kuşaklarda kamusal işlerde sorumluluk alma becerisini zedelemektedir. Hal böyleyken, eski olarak nitelenen ve dönüştüğü iddia edilen anlayışın, büyük oranda devam ettiği; dolayısıyla düşünme, sorgulama, kritik etme ve tahlil yapabilme konularında ciddi sorunlar yaşayan gençlerin, hatta üniversite mezunu insanların nüfusun çoğunluğunu oluşturduğu bir toplumun söz konusu olduğunu söylemek yanlış olmayacaktır. 
En nihayet eski, insanın eğitim vasıtasıyla ideoloji doğrultusunda yeniden kurulması, şekillendirilmesi ve bu tasarı doğrultunda yeniden işlenip yönlendirilmesi anlamında devam etmektedir (Aydoğdu, 2009: 504). Başka bir ifadeyle kendi tasarlamış olduğu düşünceye göre bireyi yaşama hazırlamayı amaçlayan ideoloji, hâlâ canlıdır. İdeoloji canlılı̆̆ını, insanı kendi özgünlügü dışında disipline ederek, kontrol altında tutarak, yeniden kurarak ve üreterek sürdürmektedir. Bu anlamda yapılması gereken, eğitimin böylesi bir işleme ameliyesi olmaktan çıkarılmasıdır. Gençler, belirli bir ideolojinin kölesi olmaktan, körü körüne bağlısı ve savunucusu olmaktan kurtarılmalıdırlar. İnsana emreden değil, onunla konuşan; insan adına düşünüp karar veren değil, ona kendi becerisi ve yetileri içerisinde düşünme ve karar verme becerisi kazandıran; insanın adına çizilmiş hayatları sorgusuz yaşayan değil, kendine yeni bir yaşam sanatı resmedebilen ve yönünü tayin edebilen bir eğitim anlayışının geçerli kılınması gerekmektedir. Daha da önemlisi Aydoğdu'nun vurgusuyla yarım ve yapay bir insan tipi yetiştirmek yerine, insanı herhangi bir şeye indirgemeden ideolojilerden arındırılarak eğitimin verildiği ve çok yönlü şahsiyetin geliştirebildiği bir eğitim düşüncesine geçilmesiyle eğitimde tek tipleşmeyi ortadan kaldırarak insan ve topluma sosyo-psişik bir denge getirilmesi sağlanmış olacak$\operatorname{tır}$ (2009: 510).

$\mathrm{Bu}$ nedenle, eski ile yeni arasında kesin bir çizgi çizilmek isteniyorsa, öncelikli olarak bireyi, onu bağımlılaştıran her şeyden kurtarmak, onu özerk ve sorumlu bir yetişkin, kelimenin en yetkin anlamıyla bir insan yapacak adımları atmak gerekmektedir. Bunun ilk adımı da eğitimi, bir bilinç uyanması olarak değerlendirmek ve bir modele göre yetişkinler üretmek olarak görmemek; her insanda kendi olmasını engelleyen şeyi açığa çıkarmak, ona kendi tekil kişisel dehasına ve bireysel keyiflerine göre olma ve yaşama imkânı tanımak (Evkuran, 2009: 482); siyaset-toplum ilişkisinde özgürlük alanını genişletmek, devletin toplumsal alana müdahale oran ve kapasitesinin sınırlandırılması yönündeki söylemlerin ve algının güçlenmesini sağlamaktan geçmektedir. Bu adımlar, söz konusu beklentiyi ve imkânı olası olmaktan çıkarıp, mümkün hale getirmektedir. Ancak bir kısmına yukarıda değinilen ve eskinin kimi yerlerde olduğu gibi devamı, kimi yerlerde de değişse bile bir kısım tortularının etkisini hissettiriyor olması, söz konusu imkânının fiili bir duruma dönüşmesini engellemektedir. Bunun için 
yapılması gerekenlerden biri de, özgürlük, bireysel özerklik, özgünlük ve çoğulculuk gibi kavramları dillendiren tartışmaların sivil alana taşınmasıdır. Altını yeniden çizmek gerekirse, devletin değil, bizzat sivil ve toplumsal aktörlerin, bu tartışmaların birincil tarafı olmaları, kendi sorunlarını tartışmaları çok önemlidir. Bu bağlamda her türden vesayetçi ilişskinin ve tahakküme dayanan anlayışın eleştirilmesi ve aşılmas1 gerekmektedir.

Vesayetçi ve tahakkümcü anlayışın aşılması da, ancak bu anlayışı üreten ideolojinin eğitim yapısının dışına itilmesi ile mümkündür. Ancak bu konuda henüz anlamlı gelişmelerin yaşandığını söylemek güçtür ve söz konusu ideoloji kısmi değişimlere uğramış olsa da varlığını sürdürmektedir. Bunun için bir adım olarak devlet-toplum ilişkisi, birey odaklı bir değerler dizisi ekseninde yeniden tanımlanmalıdır. Eğitimin yalnızca devletin ihtiyaçlarına ve keyfiliğine göre düzenlenmesine itiraz edilmeli ve toplumsal/sivil ihtiyaçlara odaklı eleştirel ve özgürlükçü bir eğitim paradigması kurgulanmalıdır. İdeolojiyi değil farklı ideolojileri tanıtan çoğulcu bir mantık ve buna uygun bir söylem geliştirilmelidir (Evkuran, 2009: 489). Bireylerin tek hakikat iddiasında olan bir ideolojiye angaje edilmeleri, doğuracağı başkaca sorunların yanı sıra, demokratik ve çoğulcu bir toplum oluşturulması önünde de büyük bir engel oluşturur. Zira demokratik ve çoğulcu bir toplum anlayışını mümkün kılan ilke, hakikatin radikal inkârı değildir. Bunun yerine daha gerçekçi ve uygulanabilir bir formül vardır. $\mathrm{O}$ da hakikat konusunun tümüyle sivil, bireysel ve entelektüel alana bırakılmasıdır. Devlet hakikatin arandığı alan değildir. Devletin varoluş nedeni, toplumsal çoğulculuğu ve kamu düzenini dengelemek ve birini diğerine feda etmeksizin her ikisini de korumaktır (Evkuran, 2009: 485). Bu nedenle, ötekinin inkârı üzerine kurulu ideolojik endoktrinasyonun yerini, kapsayıcılık, besleyicilik, duygusal ifade, barışçılık, iş birliği ve eşitlik gibi değerlerin yeniden kazandırılmasına; bireyde öteki için kaygılanma duygusunun oluşturulmasına, yani bütüncül bir benliğin inşasına bırakmalıdır (Miller, 2009: 26).

Bütüncül benlik inşası, öteki ile kurulacak diyaloğu mümkün kılması anlamında demokratik ve çoğulcu bir toplum için önemli olduğu kadar, aynı zamanda, böylesi bir demokratik toplumun eşit hak ve sorumlulukların, konuşma ve eylem özgürlüğünün, içsel bir motivasyonla katılımın ve karar verme sürecine dâhil olabilmenin hayata 
geçirebilmesi için de önemlidir (Hecht ve Ram, 2010: 27). İçsel bir motivasyonun ve kendiliğindenliğin olmadığı, bunun yerini baskının aldığı durumlarda, insan zekâsı, onun mükemmel yaratıcılığı ve özgünlügü söner. Bireyleri bir ülkenin ya da toplumun baskın inançlarına uymaya zorlamak zihinsel ve ruhsal özgürlügü azaltır; gelişme ve değişme kapasitesini sınırlandırır. İşte devlet eğitimiyle ilgili problemin temelinde, politik ve ekonomik güçlerin kişisel yaratıcılık ve bireysellik üzerinde uyguladıkları kontrolün derecesi; eğitimin sosyal ve kişisel yönleri arasında ortaya çıkan bir dengesizlik yatmaktadır (Miller, 2010: 26).

Diğer yandan eğitimin ana malzemesi olan insan, aynı zamanda demokrasinin de temel hareket noktasıdır. Dolayısıyla nasıl bir insan sorusu burada son derece önemlidir. O halde insana harcanan emeğin, yapılan yatırımların insanın yapısına, özellikle de sosyo-psişik ve kültürel yapısına uygun olması gerekir. Çünkü eğitimin bir amacı da bireyin psişik ve sosyo-kültürel niteliklerinin yok sayılması değil, çağının evrensel demokratik bilimi çerçevesinde ele alınarak sağlıklı bir "birey" ve "kimlik" olarak hayata kazandırılmasıdır (Tezcan, 1996: 62). O zaman eğitimin en genel amacı, kişinin farklı niteliklerinin yok sayılması, onların değişik şekillerde inkâr edilmesi ya da tırpanlanması değil, o nitelikleri bir ayrıcalık ve yıkıcılık olmaktan ziyade çağının felsefe ve bilimi ışığında değerlendirilerek bireyin kendi kendini tanımlamas1 ve ifade özgürlügü olarak görülmesi gerekir. Böylelikle hem "tek tip insan" ya da "şabloncu eğitim ve kimlik" tanımlamalarından kurtulmuş olunur (Aydoğdu, 2009: 504-505) ve hem de eğitim sistemindeki değerler krizi bir ölçüde aşılır. Söylenen ve öğretilen ile karmaşık gerçeklik arasındaki çelişkiden kaynaklanan değerler krizi, aynı zamanda eğitimin bu gerçekliğe ve değişime uyum sağlayabilme, farklı seslere ve görüşlere açı olabilme ve bu çeşitliliğin yardımıyla gelişebilme ve bu karşılaşmalardan karmaşık değerler oluşturabilme yeteneği ya da kapasitesi ile de doğru orantılıdır (Yaacov ve Ram, 2010: 33).

Bu kapasitenin, yani söylenen ve ögretilen ile gerçeklik arasındaki çelişkiyi ortadan kaldıracak yeteneğin harekete geçirilmesi için de, öncelikli olarak bazı temel soruların sorulması gerekmektedir: Gençler okullarımızda mutlular mı? Tüm eğitimlerinden sonra kendilerini hayata hazır hissediyorlar mı? Özgürlük ve başkasının özgürlüğü hakkında ne düşünüyorlar? Birbirlerine nazik ve saygılı davranmayı 
öğreniyorlar mı? Gençler toplumlarını, ekosistemlerini, komşularını ve uzak yerlerde acı çekenleri umursuyorlar mı? Birer kurum olarak okullar umursamaz, kişiliksiz bireyler mi yetiştiriyor yoksa insancıl, mutlu, zihinsel olarak canlı insanlar mı üretiyorlar? İçsel disiplin, azim, hoşgörü, girişim ve özgüven gibi davranışsal ve ya tavırsal becerilerin ne kadarını hangi oranda geliştirebiliyorlar? Sınırsız enerji ve meraka sahip çocukları sınıflarda hareketsiz bir şekilde oturtmaya, kendi tutkuları ve sorunlarıyla ilgisi olmayan eğitimsel görevleri yapmaya ve bazı statülere erişmek için rekabet etmeye zorlayarak hangi amaca hizmet edilebilir? Bu uygulamalar onların en yüksek insani kabiliyetlerinin doğal gelişmesine hizmet ediyor mu? Bunlar, yukarıda ele alınanlar ve daha başka bir dizi soru ve sorun üzerine düşünmek ve var olan tartışmaları derinleştirmek son derece önemli bir mesele olarak durmaktadır. Zira eğitim ve gençlikle ilgili söz konusu sorunlar, bütün bir sosyal, siyasal ve ekonomik sistemin en temelinde yatan sorunlardır.

\section{Sonuç}

Türkiye'de eğitim sistemi ve sistemin ürünleri olan gençler göz önüne alındığında eğitim sürecinin, devlet ideolojisine uygun ve uyumlu insan üretilmesi ve ideolojik olarak toplumsal itaatin devşirilmesi süreci olmaktan çıkarılmasının öncelikli bir zorunluluk olduğu dikkati çekecektir. Eğitimin uzun süre devlet eliyle vatandaşların beyninin yıkandığı yerler olarak görülmesi gerçeği, popüler söylemde artık bir hayli eleştiriliyor ve gerek siyasal seçkinlerde gerekse de bürokraside ilgi görüyor olsa da, gerekli adımlar henüz atılmış gibi gözükmüyor. Gençlerin ve eğitim sisteminin bu ağır ideolojik yüklerden bir an evvel kurtarılması gerekiyor. Başka bir ifadeyle sonuçlarla değil, artık sebeplerle uğraşmak gerekiyor.

Tüm tahsil hayatından sonra akıl yürütme, nedensellik mantı$\breve{g}$ 1 ile doğru karar verme yeteneklerini geliştirmiş, insanlık ve gelecek için yeni bir şeyler üreten, hayatın sorunları karşısında ürkmeyen ve korkmayan, dolayısıyla da korkulmayacak insanlar, bireyler olarak yetişmenin çok uzağında; dikkatini toplayamayan, ilgi ve merakını canlı tutamayan, kültür, edebiyat, sanat, estetik ve felsefe gibi alanlarla ilgisi kopmuş son derece büyük bir kitlenin varlığı üzerine konuşmak sadece sonuçları tartışmak olur. Bu durumun sebeplerini teşhisle söz konusu sonuçların/sorunların giderilmesi, ancak gençlerin eksik niteliklerini 
tamamlamalarını sağlayacak imkânları oluşturmak; muhakeme, sorgulama ve entelektüel seviyelerini arttırma istekliliğinde olacak özneler haline getirmenin çabası içerisinde olmakla mümkün gözükmektedir. Dolayısıyla eğitimi, devletin ideolojik yörüngesine ya da ihtiyaçlarına göre planlamaktan ziyade, eğiten-eğitilen ilişkisindeki özne-nesne karşıtlığını özne merkezli olarak yeniden dönüştürmek gerekmektedir. $\mathrm{Bu}$, eğitimin hem biçim ve içerik ve hem de anlam açısından yeniden ele alınmasını zorunlu kılacak bir teşebbüstür. Eğitici, derslikler, müfredat, ders materyalleri gibi konular biçim ve içerikle ilgiliyken; eğitimin devletin ideolojisine ${ }^{10}$ ve amaçlılığına hizmet eden, tek tip, uyumlu, mevcut iktidar pratiklerini içselleştirmiş insanlar yetiştirilmesinde araçsallaştırılması onun anlam yönüyle ilgilidir. Uyumluluğu ve hata yapmamayı yücelten ve yaşam için gerekli olan yaratıcıllğ 1 öldüren bu tip bir eğitim anlayışı, insanlarda, başka insanların duygu ve düşünceleriyle iletişim ve empati kurma yeteneğinin gelişmesini de köreltmektedir. Empati kuramayan, başkasını anlayamayan, duyarlı olamayan gençlerde, adalet, özgürlük ve eşitlik gibi temel insani değerlere yönelik anlamlı bir farkındalık ve ilgi de gelişememektedir. Bu nedenle yukarıda da belirtildiği gibi öncelikli olarak eğitimin, devleti merkeze alan bir ideoloji aktarma ve yayma aracı olmaktan kurtarılması gerekmektedir. Eğitim, gençler için onların eleştirel bilinç, farkındalık ve duyarlılıklarını geliştirebilecekleri ve bu sayede kendi özerkliklerinin ve özgünlüklerinin anlamını yakalayabilecekleri bir etkinlik haline getirilmelidir.

10 Eğitimin, içeriği ne kadar değiştirilirse değiştirilsin en nihayetinde politik ve sınıfsal bir karakter taşıdığı, dolayısıyla bir iktidar pratiği olması bakımından özü itibariyle ideolojik olduğu da ifade edilmektedir. Bkz. (İnal, 2010). 


\section{Kaynakça}

Anderson, C. A. (1968). Education and society. David L. Sills (Eds.), International encyclopedia of the social sciences, vol. 7. USA: The MacMillan Company and Free Press.

Anderson, M. (1996). Frontiers territory and state sormation in the modern world. Oxford: Polity Press.

Aronowitz, S. ve Girouz, H. A. (1997). Postmodern education. London: University of Minnesota Press.

Aydın, H. (2006). Eleştirel aklın ışığında postmodernizm, temel dayanakları ve eğitim felsefesi. Ĕgitimde Politika Analizleri ve Stratejik Araştırmalar Dergisi, 1 (1), 1-35.

Aydoğdu, H. (2009). Eğitimde ideolojik arayışlar: Tek tip insan ve denge sorunu. Halil Rahman Açar (Ed.), Uluslararası eğitim felsefesi kongresi bildiriler kitapçığı (ss. 500-511). Ankara: Eğitim Bir-Sen Yayınları.

Bilgin, V. (2002). 21. yüzyılda Türk modernleşmesinde paradigma değişimi. Gazi Üniversitesi İktisadi ve İdari Bilimler Fakültesi Dergisi Özel Sayısı, 65-81.

Cassirer, E. (1983). Devlet efsanesi. (Çev.: Necla Arat). İstanbul: Remzi Kitabevi.

Creveld, M. V. (2004). The rise and decline of the state. Cambridge: Cambridge University Press

Çetin, H. (2001). Devlet, ideoloji ve eğitim. Cumhuriyet Üniversitesi Íktisadi ve İdari Bilimler Fakültesi Dergisi, 25 (2): 201-211.

Çetin, H. (2007). Modernleşme krizi ideoloji ve ütopya arasında Türkiye. Ankara: Orion Yayınevi.

Dawson, R. E., Prewitt K. ve Dawson K. S. (1977). Political socialization. Boston and Toronto: Little, Brown and Company.

Dikkaya, M. ve Özyakışır, D. (2006). Küreselleşme ve bilgi toplumu: Eğitimin küreselleşmesi ve neo-liberal politikaların etkileri. Uluslararası İlişkiler, 3 (9), 151-172.

Evkuran, M. (2009). Değerler eğitimi ve eğitimde ideoloji sorunu. Halil Rahman Açar (Ed.),

Uluslararası eğitim felsefesi kongresi bildiriler kitapçı̆̆ı (ss. 460-490). Ankara: Eğitim Bir-Sen Yayınları. 
Göka, E. (2006). Insan kısım kisım: Toplumlar, zihniyetler, kimlikler. Ankara: Aşina Kitaplar.

Greenstein, F. I. (1968). Political socialization. David L. Sills, (Eds.), International encyclopedia of the social sciences vol. 14. USA: The MacMillan Company and Free Press.

Hanioğlu, Ş. (2001). Preparation for a revulation: The young Turks, 1902-1908. New York: Oxford University Press.

Hecht, Y. ve Ram, E. (2010). Demokratik eğitimde diyalog-dünyada birey. Alternatif Eğitim E-Dergisi, 1 (1), 27-45.

Heper, M. (1974). Bürokratik yönetim geleneği: Osmanlı İmparatorluğu ve Türkiye. Ankara: Ongun Kardeşler Matbaası.

Hill, D. (2003). Global neo-liberalism, the deformation of education and resistance. Journal for Critical Education Policy Studies, 1, (1): Sayfa Aralığ1 http://www.jceps.com/index. php?pageID $=$ article\&articleID $=7$, (Erişim Tarihi: 12.02.2015).

Hill, D. (2005). Globalisation and its educational discontents: Neoliberalisation and its impacts on education workers' rights, pay, and conditions. International Studies in the Sociology of Education, 15 (3), 257-288.

Hogg, M. A. ve Abrams, D. (1998). Social identifications. New York: Routledge.

Illıch, I. (1988). Şenlikli toplum. (Çev.: Ahmet Kot). İstanbul: Ayrıntı Yayınları.

İnal, K. (1999). Paternalist politikanın ideal Türk çocuğu. Ankara Üniversitesi Eğitim Bilimleri Fakültesi Dergisi, 32 (1), 195-212.

İnal, K. (2010). Eleştirel pedagoji: Eğitim(d)e modern özgürleştirici bir yaklaşım. Alternatif Ĕgitim E-Dergisi, 1 (1), 15-22.

Kadıoğlu, A. (2008). Milliyetçilik-liberalizm ekseninde vatandaşlık ve bireysellik. Tanıl Bora (Ed.), Modern Türkiye'de siyasi düşünce cilt 4 milliyetçilik (3. Bask1). İstanbul: İletişim Yayınları.

Kahraman, H. B. (2008). Türk siyasetinin yapısal analizi-I. İstanbul: Agora Kitaplığ1.

Kaplan, İ. (2005). Türkiye'de milli eğitim ideolojisi ve siyasal toplumsallaşma üzerine etkisi (4. Baskı). İstanbul: İletişim Yayınları.

Katoğlu, M. (1989). Cumhuriyet Türkiyesi'nde eğitim, kültür ve sanat. Sina Akşin (Ed.), Türkiye tarihi 4, çağdaş Türkiye 1908-1980 
(ss. 393-505). Ankara: Cem Yayınevi.

Mardin, Ş. (2006). Tanzimat'tan sonra aşırı Batılılaşma. Ersin Kalayc1oğlu ve Ali Yaşar Sarıbay (Ed.), Türk siyasal hayatının gelişimi (ss. 29-71). İstanbul: Beta Yayınları.

Miller, R. (2010). Eğitim alternatifleri niçin var?. Alternatif Ĕgitim E-Dergisi, 1 (1), 24-27.

Poggi, G. (2005). Modern devletin gelişimi sosyolojik bir yaklaşım. (Çev.: Şule Kut ve Binnaz Toprak, 3. Bask1). İstanbul: İstanbul Bilgi Üniversitesi Yayınları.

Rusk, R. R. (1965). The doctrines of the great educators. Melbourne, London and Toronto: MacMillian.

Schulze, H. (2005). Avrupa'da ulus ve devlet. (Çev.: Timuçin Binder). İstanbul: Literatür Yayınları.

Smith, R ve Wexler, P. (2005). After postmodernism: Education, politics and identity. Washington: The Falmer Press.

Tezcan, M. (1996). Eğitim sosyolojisi (10. Bask1). Ankara: Feryal Matbaas1.

Toynbee, A. J. ve Kenneth P. K. (1927). Turkey. New York: Charles Scribner's and Sons.

Üstel, F. (2009). Makbul vatandaşın peşinde. İstanbul: İletişim Yayınlar1.

Wight, M. (1977). Systems of state, Leicester. Leicester: U. Press.

Yanık, C. (2013). Etnisite, kimlik ve milliyetçilik kavramlarının sosyolojik analizi. Kaygl, 20, 225-237. 